\title{
Implementation of Legal Protection Against The Criminal Acts of Children \& Witnesses in The Criminal Action of Stealing
}

\author{
Meta Permatasari*) and Umar Ma'ruf ${ }^{* *}$
}

*) Student of Master of Law, Universitas Islam Sultan Agung Semarang and Civil Servant Prosecutor of Semarang, E-mail: meta.jks@gmail.com

${ }^{* *}$ ) Faculty of Law, Universitas Islam Sultan Agung Semarang

\begin{abstract}
.
The method used in this research is sociological research methods. This approach is directed at the setting and the individual holistically (intact). So, in this case it is not permissible to isolate individuals or organizations into variables or hypotheses, but it is necessary to see them as part of a whole. The purpose of this research is to analyze and explain: 1) The factors that encourage children to commit the crime of theft in the jurisdiction of the Semarang City District Attorney, 2) Implementation of Legal Protection for Child Perpetrators and Witnesses in the Crime of Theft in order to realize the principle of best interests Children in the Semarang City District Attorney, 3) Factors that hinder the implementation of legal protection for child perpetrators and witnesses in the crime of theft in order to realize the principle of the best interests of children in the Semarang City District Attorney and what is the solution. The results showed that The factors that encourage children to commit criminal acts of theft include: family, education, economy, social factors. The implementation of legal protection for children of perpetrators and witnesses in criminal acts of theft, namely by making efforts to resolve children's cases outside the judicial process, preventing children from being deprived of liberty, encouraging the public to participate and instilling a sense of responsibility to children. Factors that hinder the legal protection of children of perpetrators and witnesses in criminal acts of theft, namely: the investigation procedure file submitted by the investigator to the public prosecutor does not completely and clearly describe the perpetrator and victim in the occurrence of a criminal act.

Keywords: Legal Protection; Crime; Thieving; Children.
\end{abstract}

\section{Introduction}

In order to realize a prosperous, just and prosperous Indonesian society based on Pancasila and the 1945 Constitution of the Republic of Indonesia, the quality of Indonesia's human resources as one of the assets for national development needs to be continuously improved, including increasing attention to adolescents or children. They as wealth and potential human resources for the Indonesian nation in the future. ${ }^{1}$

Before children grow and develop into adulthood, beforehand, these children will experience the period or world of children. Therefore, every child needs to get the widest possible opportunity to grow and develop optimally both physically, mentally, socially and with noble character. Efforts to protect and foster children

\footnotetext{
${ }^{1}$ Soetodjo, Wagiati. (2005). Hukum Pidana Anak. , Bandung: PT Refika Aditama. p. 5.
} 
need to be carried out by providing guarantees for the fulfillment of their rights and treatment without discrimination. ${ }^{2}$

Talking about children and their protection will never stop throughout the history of life, because children are the next generation of development, namely the generation that is prepared to be the object of implementing sustainable development and in control of the future of a country, including Indonesia. ${ }^{3}$

Deviant behavior according to WA Gerungan which tends to lead to criminal acts committed by the child in the form of a criminal act is classified as delinquency 4 . Apart from the factors that become the motive for the occurrence of a criminal act, a criminal act is also committed by using various methods or modus operandi as well as the perpetrator committing the crime. ${ }^{5}$

Seeing the above phenomena, the authors are interested in further examining the factors that encourage children to commit the crime of theft, the implementation of legal protection for child perpetrators and witnesses in the crime of theft, factors that hinder the implementation of legal protection for child perpetrators and Witnesses in the Crime of Theft in the context of realizing the principle of the best interests of children at the Semarang City District Attorney and the solution.

Based on the background description of the problem above, the objectives to be achieved are: to identify and analyze the factors that encourage children to commit the crime of theft in the jurisdiction of the Semarang City District Attorney; Implementation of Legal Protection for Child Perpetrators and Witnesses in the Crime of Theft in the Context of Realizing the principle of the best interests of Children at the Semarang City District Attorney and the factors that hinder the implementation of legal protection for the child perpetrators and witnesses in the crime of theft in order to realize the best interests principle for Children at the Semarang City District Attorney and the solution.

\section{Research methods}

The approach method used in this research is sociological research methods. The research specification in this research is descriptive, that is, a study that only describes the main object only problem ${ }^{6}$.

In this study, the data used by the researcher is primary data, namely data taken directly from research informants, namely the Semarang City Public Prosecutor's Office and the Semarang Police. Meanwhile, the secondary data taken consists of primary legal materials, secondary legal materials and tertiary legal materials.

This data collection was carried out through the following research stages: Library research; Field research; Interview. Data analysis in this study used a qualitative

\footnotetext{
${ }^{2}$ Amin Purnawan, Bambang Purnomo, Gunarto. (2018). Penegakan Hukum Tindak Pidana Anak Sebagai Pelaku Dalam Sistem Peradilan Pidana Anak (Studi Kasus Di Polres Tegal), Jurnal Hukum Khaira Ummah Vol. 13. No. 1 March 2018, jurnal.unissula.ac.id.jhku.article. p.46\|

${ }^{3}$ Nashriana. (2011). Perlindungan Hukum Pidana Bagi Anak Di Indonesia, Jakarta: Raja Grafindo. p. 1. ${ }^{4}$ Gerungan, W.A. (1996). Psikologi Sosial Suatu Ringkasan, Bandung: Eresco. p. 27.

5Tongat. (2012). Perspektif Perkembangan Hukum di Indonesia, Malang: UMM Press. p. 41

${ }^{6}$ Hanitijo, Ronny. (1990). Metode Penelitian Hukum dan Jurimetri, Jakarta: Ghalia Indonesia. p. 13
} 
method which is a research procedure that produces descriptive data in the form of written or spoken words from people and observable behavior. ${ }^{7}$

\section{Result and Discussion}

\subsection{The factors that encourage children to commit the crime of theft in the jurisdiction of the Semarang City District Attorney}

According to the explanation of the Head of the Semarang City District Attorney, the factors that encourage children to commit the crime of theft are: ${ }^{8}$ The influence of science and technology is increasingly advanced; Parental disharmony; As a result of promiscuity that comes from the environment; Due to the weak family economy.

According to Djamil, 2013, the increasing number of crimes committed by minors states that there are two categories of children's behavior so that they must face the law, namely:

- Offence Status, is a child's delinquency which, if committed by an adult, is not considered a crime, such as disobeying, hiding other people's belongings/children, skipping school, or running away from home.

- Juvenile Deliquency, is delinquency behavior of children which if done by adults is considered a crime or violation of the law. ${ }^{9}$

The crime of theft committed by children does not occur automatically, but is caused by several factors that encourage children to commit theft. There are two forms of motivation, namely:

- Intrinsic motivation

Intrinsic motivation is a desire or impulse in a person that does not need to be accompanied by external stimuli, which include: Intelligence factor is a person's intelligence or a person's ability to weigh and give decisions; Age factor. Age is the most important factor in the causes of crime; Gender factor. Child delinquency can be committed by both men and women. Gender differences also result in differences in the quality of their delinquency.

- Extrinsic motivation

Extrinsic motivation is motivation or encouragement that comes from outside a person which includes:

a. Family factor.

b. Education and school factors.

c. Social factors; The influence of the media ${ }^{10}$

According to Marlina in her book entitled Child Criminal Justice in Indonesia, states that the causes of children committing crimes include: Social influence; Lack of

\footnotetext{
7 Ibid. p. 3.

8 The results of the author's interview with Sumurung P Simaremare, as the Head of the Semarang City Public Prosecutor's Office, accessed on September 21, 2020.

${ }^{9}$ M. Nasir, Djamil. (2013). Anak Bukan Untuk Dihukum (Catatan Tentang Pembahasan Undang Undang Sistem Peradilan Anak, UU-SPPA). Jakarta: Sinar Grafika, Jakarta. P. 33

${ }^{10}$ Soetodjo, Wagiati. (2008). Hukum Pidana Anak, Bandung: Refika Aditama. p. 25
} 
attention from both parents and family; Broken home family (broken family); Economy. Low economic level; Low level of education. ${ }^{11}$

According to AS Alam, the causes of crime, namely: Anomie (absence of norms) or strain (tension), Cultural Deviance, and Social Control.12 Meanwhile, according to Abdulsyani, from a correctional perspective, a person who commits a crime is an outside influence. A person is always colored by the condition of his family, environment, and society. ${ }^{13}$

Crime is a never-ending social phenomenon to be studied, this is because crime is increasingly developing along with the development of human life. Crime as a social phenomenon is more influenced by various aspects of life in society such as politics, economy, socio-culture and matters related to defense and security efforts. ${ }^{14}$

\subsection{Implementation of Legal Protection for Child Perpetrators and Witnesses in the Crime of Theft in the Context of Realizing the principle of the best interests of children}

Legal protection is a protection provided to legal subjects in accordance with legal rules, both in a Preventive nature or in a form that is repressive (coercion). Meanwhile, the form of legal protection for minors who commit criminal acts during the examination process at the trial itself is in Act No. 3 of 1997 concerning Juvenile Court in Article 6 which states "Judges, Public Prosecutors, Investigators, and Legal Counselors and officers". The others in the juvenile congregation did not wear a gown or official attire. ${ }^{15}$

That the process during the trial of children does not mean to punish but to help, nurture and guide children towards maturity. In addition, avoiding a court atmosphere that is formalistic in nature frightens the child by allowing it to have a more negative influence on the mental development of the child. So that criminal prosecution of children must indeed be different from criminal prosecution of adults. Children are given the lightest possible punishment and half of the sentence for adult criminals. Children who violate the law of theft should be punished with crimes that are educational and foster children towards a better life, so that they become members of society who obey the law. Therefore, the nature of sanctions or actions for children must be different from the nature of criminal sanctions for adults. ${ }^{16}$

The judge examines the case of the child who has committed the crime of theft in a closed court. This is intended to create an atmosphere of calm, and full of

\footnotetext{
11Marlina. (2007). Peradilan Pidana Anak di Indonesia, Bandung: Refika Aditama. p. 65-66.

${ }^{12}$ Alam, AS. (2010). Pengantar Kriminologi, Makassar: Pustaka Refleksi. p. 45-46

13 Abdulsyani. (1987). Sosiologis Kriminalitas, Bandung: CV.Remadja Karya. p. 44.

14 Utari, Indah Sri. (2012). Aliran dan Teori dalam Kriminologi, Yogyakarta: Thafa Media. p. 23.

15 The results of the author's interview with Sumurung P Simaremare, as the Head of the Semarang City Public Prosecutor's Office, accessed on September 21, 2020

${ }^{16}$ Sri Endah Wahyuningsih, Setyo Hartanto. (2017). Proses Penyidikan dan Penuntutan Tindak Pidana Pencurian Yang Dilakukan Oleh Anak Di Wilayah Kabupaten Semarang, Jurnal Hukum Hukum Khaira Ummah Vol. 12. No. 3 September 2017: $677 \quad$ - 684. garuda.ristekbrin.go.id.journal.view.
} 
kinship so that children can express all events and all their feelings openly and honestly during the trial. ${ }^{17}$. And the examination of the juvenile trial is basically carried out with a single judge, with the aim that the children's trial can be completed quickly. ${ }^{18}$

Judges in the children's trial play a role in examining and deciding cases of children with the fairest decision possible, taking into account and considering the household conditions of their parents or guardians, the relationship between family members and the environmental conditions of the child concerned with the aim that the child can meet his future. with the best possible. ${ }^{19}$

Based on the authority of the Prosecutor's Office, one of which is to carry out the prosecution, so in relation to the child the prosecution process has a specificity. Article 42 of Act No. 11 of 2012 concerning the Juvenile Justice System states that ${ }^{20}$ :

- The Public Prosecutor is obliged to seek Diversion within no later than 7 (seven) days after receiving the case files from the Investigators.

- Diversion as referred to in paragraph (1) shall be carried out for a maximum of 30 (thirty) days.

- In the event that the Diversion process succeeds in reaching an agreement, the Public Prosecutor submits the Diversion report along with the Diversion agreement to the head of the district court to make a decision.

- In the event that the Diversion fails, the Public Prosecutor is obliged to deliver an official report of the Diversion and delegate the case to the court by attaching a social research report.

Law enforcement also includes diversion. The diversion process is carried out to create restorative justice, both for children and for victims. Restorative justice is a process of diversion, where all parties involved in a certain criminal act jointly solve problems and create an obligation to make things better by involving victims, children, and society in finding solutions to improve, reconcile, and reassuring that is not based on vengeance. ${ }^{21}$

The public prosecutor shall conduct the finalization since receiving the file from the investigator and then examine the file with a maximum period of 7 (seven) days. At the same time as the examination of the files, the Public Prosecutor also conducts diversion for criminal offenses with a threat of less than 7 (seven) years and is not a recidivist (repetition). ${ }^{22}$

\footnotetext{
${ }^{17}$ Soetodjo, Wagiati.2006, Hukum Pidana Anak, Bandung: Refika Aditama. p. 35

18 The results of the author's interview with Nofiati Djamiah, SH.MH., As the Semarang City Public Prosecutor's Prosecutor, accessed on September 24, 2020.

19Dellyana, Shanty. (1990). Wanita Dan Anak Di Mata Hukum, Yogyakarta: Liberty. p. 13

20 The results of the author's interview with Adiana Windawati, SH.MHum., As the Semarang City Public Prosecutor's Prosecutor, accessed on September 24, 2020.
${ }^{21}$ Umar Ma'ruf, Anita Indah Setyaningrun. (2017). Diversi Sebagai Bentuk Penyelesaian Perkara Pidana Anak Melalui Pendekatan Restorative Justice Oleh Penyidik Polda Jawa Tengah, Jurnal Hukum Khaira Ummah Vol. 12. No. 4 December 2017. Universitas Islam Sultan Agung, Semarang, p. 975-980. 22 The results of the author's interview with Adiana Windawati, SH.MHum., As the Semarang City Public Prosecutor's Prosecutor, accessed on September 24, 2020.


The scope of law enforcement also includes restorative justice, which is a settlement process carried out outside the criminal justice system by involving victims, perpetrators, victims' families and communities as well as parties with an interest in a criminal act that occurs to reach an agreement and completion ${ }^{23}$.

This is in accordance with the opinion (Sri Endah Wahyuningsih, Rismanto, 2016) that a rule of law is a state that enforces the law optimally, upholds human rights and guarantees citizens equal position in the law and the government is obliged to uphold law and government with no exception. So law enforcement is one of the parameters in the success of a rule of law. ${ }^{24}$

The Semarang City Public Prosecutor's Office has made restorative and diversionary efforts because it is an obligation carried out because it aims to achieve peace between victims and children, resolve child cases outside the judicial process, prevent children from being deprived of independence, encourage the community to participate, and instill a sense of responsibility towards children. This effort is carried out in the event that the criminal act committed is punishable by imprisonment of less than 7 (seven) years and does not constitute a repetition of the criminal act. ${ }^{25}$

\subsection{Factors that hinder the implementation of legal protection for child perpetrators and witnesses in the crime of theft in order to realize the principle of the best interests of children at the Semarang City District Attorney and what is the solution}

According to the Head of the Semarang City Public Prosecutor's Office, the factors that hinder the implementation of legal protection for child perpetrators and witnesses in criminal acts of theft in order to realize the principle of the best interests of children in the Semarang City Public Prosecutor's Office, namely:

- There are differences in perceptions about the meaning of justice by the perpetrators of diversion, both from the victims and/or their families, perpetrators and/or their families, law enforcement officials, Bapas, social workers, community leaders, psychologists, educators and NGOs (NonGovernmental Organizations that are concerned about the implementation of diversion).

- The community paradigm which assumes that every crime that is committed has a reward (restributive justice).

\footnotetext{
${ }^{23}$ Anis Mashdurohatun, Rully Trie Prasetyo, Umar Ma'ruf. (2017). Tindak Pidana Korporasi Dalam Perspektif Kebijakan Formulasi Hukum Pidana, Jurnal Hukum Khaira Ummah, Vol 12, No.4, Universitas Islam Sultan Agung Semarang, p. 727-741.

${ }^{24}$ Rismanto, Sri Endah Wahyuningsih. (2015). Kebijakan Penegakan Hukum Pidana Terhadap Penanggulangan Money Laundring Dalam Rangka Pembaharuan Hukum Pidana Di Indonesia, Jurnal Pembaharuan Hukum, Volume II No. 1 January - April 2015. Universitas Islam Sultan Agung Semarang.

25 The results of the author's interview with Sumurung P Simaremare, as the Head of the Semarang City Public Prosecutor's Office, accessed on September 21, 2020
} 
- The victim did not want to forgive the perpetrator because of the losses suffered by the victim. ${ }^{26}$

According to the explanation of the Head of the Semarang City District Attorney, that the obstacles experienced include:

- The investigation procedure file submitted by the investigator to the public prosecutor does not completely and clearly describe the perpetrator and victim in the occurrence of the criminal act.

- Lack of knowledge and ability of the prosecutor in carrying out prosecution by looking at the perpetrator and victim in the criminal act of thieves

The solutions for overcoming legal protection barriers include: 27

- Providing socialization on the settlement of criminal cases committed by children to prioritize the interests of the child while ignoring the personal interests of the institution.

- It can only be done by revising the provisions on the penalty threshold for no longer 7 (seven) years. However, this is not an easy matter because the government has considered many things based on philosophical, psychological, pedagogical and sociological studies, so that if it is to change the threat of punishment for no longer being seven years, it is necessary to conduct a similar study first.

- Optimizing outreach on the prevention of criminal acts of theft against children, adolescents, and parents.

\section{Closing}

The factors that encourage children to commit the crime of theft, among others: family factors, educational factors, factors, economy, social factors. The implementation of legal protection for children of perpetrators and witnesses in criminal acts of theft, namely by making efforts to resolve children's cases outside the judicial process, preventing children from being deprived of liberty, encouraging the public to participate, and instilling a sense of responsibility to children. Factors that hinder the legal protection of children of perpetrators and witnesses in criminal acts of theft, namely: the investigation procedure file submitted by the investigator to the public prosecutor does not fully and clearly describe the perpetrator and victim in the occurrence of a criminal act, the community paradigm which assumes that every crimes committed have a retribution (restributive justice), and a negative paradigm of society towards law enforcement.

The suggestions that the researcher can summarize are as follows: The government needs to provide broad access to prosecutors to take part in the Training of Handling Crime of Children Dealing with the Law; The Semarang Public Prosecutor's Office should always carry out activities to provide legal counseling or internal socialization to children and parents in the context of preventive efforts.

\footnotetext{
26 The results of the author's interview with Sumurung P Simaremare, as the Head of the Semarang City Public Prosecutor's Office, accessed on September 21, 2020

27 The results of the author's interview with Sumurung P Simaremare, as the Head of the Semarang City Public Prosecutor's Office, accessed on September 21, 2020
} 


\section{References}

\section{Journals}

[1] Amin Purnawan, Bambang Purnomo, Gunarto.(2018). Penegakan Hukum Tindak Pidana Anak Sebagai Pelaku Dalam Sistem Peradilan Pidana Anak (Studi Kasus Di Polres Tegal), Jurnal Hukum Khaira Ummah Vol. 13. No. 1 March 2018.

[2] Anis Mashdurohatun, Rully Trie Prasetyo, Umar Ma'ruf.(2017). Tindak Pidana Korporasi Dalam Perspektif Kebijakan Formulasi Hukum Pidana, Jurnal Hukum Khaira Ummah, Vol 12, No.4, Universitas Islam Sultan Agung Semarang.

[3] Rismanto, Sri Endah Wahyuningsih.(2015). Kebijakan Penegakan Hukum Pidana Terhadap Penanggulangan Money Laundring Dalam Rangka Pembaharuan Hukum Pidana Di Indonesia, Jurnal Pembaharuan Hukum, Volume II No. 1 January - April 2015. Universitas Islam Sultan Agung Semarang.

[4] Sri Endah Wahyuningsih, Setyo Hartanto.(2017). Proses Penyidikan dan Penuntutan Tindak Pidana Pencurian Yang Dilakukan Oleh Anak Di Wilayah Kabupaten Semarang, Jurnal Hukum Hukum Khaira Ummah Vol. 12. No. 3 September 2017: 677 - 684. garuda.ristekbrin.go.id.journal.view.

[5] Umar Ma'ruf, Anita Indah Setyaningrun.(2017). Diversi Sebagai Bentuk Penyelesaian Perkara Pidana Anak Melalui Pendekatan Restorative Justice Oleh Penyidik Polda Jawa Tengah, Jurnal Hukum Khaira Ummah Vol. 12. No. 4 December 2017. Universitas Islam Sultan Agung, Semarang.

\section{Books}

[1] Abdulsyani. (1987). Sosiologis Kriminalitas, Bandung: CV. Remadja Karya.

[2] Alam, A.S.(2010). Pengantar Kriminologi, Makassar: Pustaka Refleksi.

[3] Dellyana, Shanty.(1990). Wanita Dan Anak Di Mata Hukum, Yogyakarta: Liberty.

[4] Gerungan, W.A.(1996). Psikologi Sosial Suatu Ringkasan, Bandung: Eresco.

[5] Hanitijo, Ronny.(1990). Metode Penelitian Hukum dan Jurimetri, Jakarta: Ghalia Indonesia.

[6] M. Nasir, Djamil.(2013). Anak Bukan Untuk Dihukum (Catatan Tentang Pembahasan Undang Undang Sistem Peradilan Anak, UU-SPPA). Jakarta: Sinar Grafika.

[7] Marlina.(2007). Peradilan Pidana Anak di Indonesia, Bandung: Refika Aditama.

[8] Nashriana.(2011). Perlindungan Hukum Pidana Bagi Anak Di Indonesia, Jakarta : Raja Grafindo.

[9] Soetodjo, Wagiati.(2008). Hukum Pidana Anak, Bandung: Refika Aditama.

[10] Tongat.(2012). Perspektif Perkembangan Hukum di Indonesia, Malang: UMM Press.

[11] Utari, Indah Sri.(2012). Aliran dan Teori dalam Kriminologi, Yogyakarta: Thafa Media. 